Original article

\title{
Dietary practice during pregnancy and associated factors among pregnant women in Farta district, South Gondar Zone, Northwest Ethiopia, 2021
}

\author{
Wagaye Shumete Belay ${ }^{\mathrm{a}}$, Endeshaw Admasu Cherkos ${ }^{\mathrm{b}}$, Eden Bishaw Taye ${ }^{\mathrm{c}, *}$

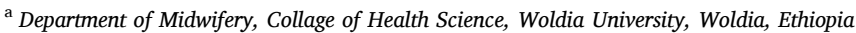 \\ ${ }^{\mathrm{b}}$ Department of Women's and Family Health, School of Midwifery, College of Medicine and Health Sciences, University of Gondar, Gondar, Ethiopia \\ ${ }^{\mathrm{c}}$ Department of Clinical Midwifery, School of Midwifery, College of Medicine and Health Sciences, University of Gondar, Gondar, Ethiopia
}

\section{A R T I C L E I N F O}

\section{Keywords:}

Dietary practice

Pregnant mothers

Farta district

Ethiopia

\begin{abstract}
A B S T R A C T
Introduction: Maternal undernutrition in low and middle-income countries is an underlining cause for more than 3.5 million deaths and disabilities. Maternal malnutrition during pregnancy increases the risk of gestational anemia, hypertension, miscarriages, and fetal deaths during pregnancy, preterm delivery, and maternal mortality.

Method: A community-based cross-sectional study was conducted from March 1 to April 1, 2021. A total of 615 pregnant women participated in the study. All eligible pregnant women were identified through a house-to-house visit with the help of health extension workers. The cluster sampling method was used to select the study participant. A pre-tested structured interviewer administered questioner was used. Filled questionnaires were checked, coded, and entered into EPI data version 4.6 and exported to SPSS version 23 software. A bivariate and multivariable logistic regression model was fitted to identify associated factors. An adjusted odds ratio with a 95\% confidence interval was computed to determine the level of significance.

Result: This study has shown that only $27.2 \%$ of pregnant mothers had good dietary practices. In multivariable logistic regression analysis; average monthly income ( $\geq 3500$ ETB) [AOR: 12.03 (95\% CI: 2.83,51.17)], family size (1-3) [AOR: 5.66 (95\% CI: 2.03,15.83)] \& (4-6) [AOR: 2.84 (95\% CI: 1.05, 7.67)], educational status (formal education) [AOR:7.61 (95\% CI: 3.64,15.91)] and dietary knowledge [AOR: 1.99 (95\% CI: 1.27, 3.12)] were the factors significantly associated with good dietary practices.

Conclusion: In this study, more than a quarter of pregnant mothers had good dietary practice. Educational status of the participant, dietary knowledge, monthly income, and family size was significantly associated with dietary practices of pregnant women. To improve dietary practice of pregnant women; enhance knowledge on nutrition through nutrition education and decrease family size by regular family planning counseling in the continuum of maternal care.
\end{abstract}

\section{Introduction}

Pregnancy is a period when nutrient intake is extremely important to meet the mother's usual requirements, needs of the growing fetus, and to store nutrients required for fetal development and lactations. ${ }^{1}$ So, better nutrition is related to improved infant, child, and maternal health, stronger immune systems, safer pregnancy and childbirth, lower risk of non-communicable diseases (such as diabetes and cardiovascular disease), and longevity. ${ }^{2}$

Malnutrition in every form presents a significant and complex problem across the world. ${ }^{3,4}$ Today the world faces a double burden of malnutrition that includes both undernutrition and overweight, especially in low-and middle-income countries. ${ }^{2}$ Maternal undernutrition in low and middle-income countries causes more than 3.5 million maternal and under-five children to death and permanently disabled by the physical and mental effects of a poor dietary intake in the earliest months of life. ${ }^{5}$ It also contributes to 800,000 neonatal deaths annually and stunting, wasting, and micronutrient deficiencies are estimated to cause nearly 3.1 million child deaths annually. ${ }^{6}$

Maintaining good nutrition and a healthy diet during pregnancy is

Abbreviations: ANC, antenatal care; AOR, adjusted odds ratio; CI, confidence interval; BSC, Bachelor of Science; COR, Crud Odds Ratio; EDHS, Ethiopian Demographic Health Survey; ETB, Ethiopian Birr; SDGs, Sustainable Development Goals; SPSS, Statistical Package for Social Science.

* Corresponding author. Po. Box 196, Gondar, Ethiopia.

E-mail address: edbishaw16@gmail.com (E.B. Taye). 
essential for the health of both the mother and her child. ${ }^{7}$ Maternal malnutrition during pregnancy increases the risk of gestational anemia, obstructed labor, postpartum hemorrhage, preeclampsia, miscarriages, and fetal deaths during pregnancy, preterm delivery, and maternal mortality. ${ }^{1,8}$ For the newborn, it can cause low birth weight, stillbirth, birth asphyxia, preterm birth, neonatal death, and fetal intrauterine growth retardation that may have long-life consequences on newborn development. ${ }^{3,8}$ Good maternal nutrition before, during, and between pregnancies could avoid health problems like: risk of fetal and infant mortality, intrauterine growth retardation, low birth weight, premature births, birth defects, cretinism, poor brain development, and risk of infection. ${ }^{9}$

Ethiopia is one of the developing nations with a high burden of maternal and child undernutrition. A systemic review and meta-analysis which was done from 2008 up to 2018, from African pregnant women $23.5 \%$ were malnourished, the pooled prevalence of malnutrition was higher in Ethiopia that was 26\%. ${ }^{10}$ The 2018 Ethiopian demographic and health survey (EDHS) report indicates that 22\% of women's reproductive ages were undernourished, while $8 \%$ are overweight or obese and $29 \%$ were anemic in addition to the prevalence of undernutrition in the Amhara region is $22.9 \%{ }^{11}$ A study in the rural parts of Ethiopia showed that; poor dietary practice during pregnancy increases the risk of maternal anemia by twofold, low birth weight by 4-7 fold, and preterm delivery by 2 fold when compared with good dietary practice. ${ }^{12}$ To relieve the burden of undernutrition; the government of Ethiopia has placed programs and initiatives with set targets and the national nutrition program was also launched in $2008 .{ }^{13}$ However, maternal undernutrition remains a major public health concern.

Evidences might be important to support the progress of interventions being taken by the country.

Moreover, as far as our knowledge there are limited studies regarding dietary practice and associated factors during pregnancy in a rural part of Ethiopia, especially in the Amhara region. So, this study tries to provide directions for both governmental and non-governmental bodies about dietary practices during pregnancy.

\section{Methods and materials}

\subsection{Study design, setting, and period}

A community-based cross-sectional study design was conducted from March 1 to April 1, 2021, in Farta district, Northwest Ethiopia. Farta district is found in the South Gondar Zone. It is bordered on the South by Misrak Este, on the West by Fogera, on the North by Ebenat, and on the East by Lay Gayint. The district has 33 kebeles (small administrative units in Ethiopia), 7 health centers, and 54 health posts. A total of 56,579 reproductive-age women are found in the area. ${ }^{14}$

\subsection{Study population}

All pregnant women who live in the Farta district were the source population. All pregnant women who live in the Farta district in selected clusters were the study population.

\subsection{Inclusion and exclusion criteria}

All pregnant women who lived for at least six months in the study area and were healthy (self-reported) were included. Pregnant women with confirmed diabetes mellitus at the time of data collection were excluded.

\subsection{Sample size and sampling techniques}

The sample size was calculated using the single population proportion formula. Based on previous research findings on the prevalence of good dietary practice during pregnancy $39.3 \%,{ }^{15}$ using a margin of error
(0.05), at 95\% confidence level $(\mathrm{Z} \alpha / 2=1.96)$;

$n=\frac{\left(\frac{\mathrm{Za}}{2}\right) 2 * \mathrm{P}(1-\mathrm{P})}{\mathrm{d} 2}$

$n=\frac{(1.96) 2 * 0.39(1-0.39)}{(0.05) 2}$

$n=360$

By considering $10 \%$ non-response rate and 1.5 designing effect the final sample size was 609 .

Among thirty-three kebeles (small administrative units in Ethiopia); six kebeles (Mahider-Mariam, Gena-Mechawecha, Gassay, Qusquam, Debre-Eyesus, and Hiruy-Abaregay) were selected as a cluster by simple random sampling method. All pregnant mothers in the selected clusters were included in the study.

\subsection{Operational definition}

Good dietary practice: There are fifteen dietary assessing questions. A woman has good dietary practice if she scored at least $75 \%$ of dietary practice assessing questions. ${ }^{16}$

Poor dietary practice: There are fifteen dietary assessing questions A woman has poor dietary practice if she scored less than $75 \%$ of dietary practice assessing questions. ${ }^{16}$

Good knowledge: A woman has good nutritional knowledge if she scored at least $75 \%$ of nutritional knowledge assessing questions. ${ }^{17}$

Poor knowledge: A woman has poor nutritional knowledge if she scored less than $75 \%$ of nutritional knowledge assessing questions. ${ }^{17}$

\subsection{Data collection tools and procedures}

The data was collected using a structured and intervieweradministered questionnaire. The questionnaire had four parts. These were socio-demographic, pregnancy and obstetrics, knowledge of nutrition, and nutritional practice. The questionnaires were adapted from different literatures. The data collection tool was prepared in English and then translated into the local language (Amharic) and then retranslated back to English to keep consistency. Data collection was done by three BSc Midwives as collectors and two MSc Midwives as a supervisor. All responses to closed and open questions were written down manually by the interviewers. The supervisors assessed the consistency and completeness of data on daily basis.

\subsection{Data quality assurance}

One-day training was given for data collectors and supervisors about the purpose of the study, data collection tools, collection techniques, and ethical issues during the selection of participants and collection of the data. The tool was pretested on $5 \%$ of the actual sample size at Fogera district. During data collection, each data collector was supervised for any difficulties and direction and the necessary correction was provided. The collected data was cheeked for its completeness every day before the following day of data collection by supervisors and the principal investigator and corrective measures were taken according to the finding during supervision.

\subsection{Data processing and analysis}

Data were entered into EPI data version 4.6 and exported to SPSS version 23 for analysis. Variables that have an independent association with the dietary practice were identified based on AOR, with 95\% CI and p-value less than 0.05. Descriptive statistics like percentage, mean and standard deviation were used for the presentation of data. 


\section{Results}

\subsection{Socio-demographic characteristics of study participants}

In this study, a total of 615 pregnant mothers have participated. The mean age with SD of pregnant mothers was $28.05 \pm 5.23$ and the range of $18-42$. Ninety-eight percent of the participants were married. The majority (98.7\%) were orthodox Christian. Six hundred seven (99.5\%) were in the Amhara ethnic groups. More than half (66.7\%) of the participants were unable to read and write. A majority (92.2\%) of the study participants were housewives. Concerning monthly income, about $32.7 \%$ of the participants earn less than 2000 Ethiopian birr. Sixty-nine percent of the participants have a family size greater than four. Most (91.9\%) of the participants' residence was rural (Table 1).

\subsection{Obstetric and pregnancy-related characteristics of pregnant mothers}

Concerning obstetric and pregnancy-related characteristics, more than half $(51.5 \%)$ of the pregnant mothers were in the third trimester, followed by $38 \%$ of pregnant mothers were at the second trimester. Concerning women's previous pregnancies, $65.5 \%$ of pregnant mothers had 3-5 previous pregnancies. A $66.6 \%$ of the participants had a party of three to five. Eighty-seven percent of women had 3-5 years interpregnancy interval. Regarding history of child death, $4.8 \%$ of pregnant mothers had child death history and from this $25.9 \%$ was neonatal death. Regarding the place of delivery of the last baby, $89.8 \%$ of participants gave birth at health institutions (Table 2).

Table 1

Socio-demographic characteristics of pregnant mothers in Farta district, South Gondar Zone, Northwest Ethiopia, 2021 (n = 615).

\begin{tabular}{|c|c|c|c|}
\hline Variables & & Frequency & $\begin{array}{l}\text { Percent } \\
(\%)\end{array}$ \\
\hline \multirow[t]{3}{*}{ Age } & $\leq 19$ & 14 & 2.3 \\
\hline & $20-29$ & 396 & 64.4 \\
\hline & $\geq 30$ & 205 & 33.3 \\
\hline \multirow[t]{3}{*}{ Marital status } & Single & 9 & 1.5 \\
\hline & Married & 602 & 97.8 \\
\hline & Separated & 4 & 0.7 \\
\hline \multirow[t]{2}{*}{ Religion } & Orthodox & 607 & 98.7 \\
\hline & Muslim & 8 & 1.3 \\
\hline \multirow[t]{2}{*}{ Ethnicity } & Amhara & 612 & 99.5 \\
\hline & Oromo & 3 & 0.5 \\
\hline \multirow[t]{3}{*}{ Educational status } & $\begin{array}{l}\text { unable to read and } \\
\text { write }\end{array}$ & 410 & 66.7 \\
\hline & able to read and write & 139 & 22.6 \\
\hline & formal education & 66 & 10.7 \\
\hline \multirow[t]{3}{*}{$\begin{array}{l}\text { Husband's educational } \\
\text { status }\end{array}$} & $\begin{array}{l}\text { unable to read and } \\
\text { write }\end{array}$ & 396 & 64.4 \\
\hline & able to read and write & 146 & 23.7 \\
\hline & Formal education & 73 & 11.9 \\
\hline \multirow[t]{4}{*}{ Occupation } & House wife & 569 & 92.5 \\
\hline & Farmer & 31 & 5.0 \\
\hline & Government employee & 7 & 1.1 \\
\hline & Other $^{\mathrm{a}}$ & 8 & 1.4 \\
\hline \multirow[t]{3}{*}{ Husband's occupation } & Farmer & 564 & 91.7 \\
\hline & Government employee & 15 & 2.4 \\
\hline & Other $^{\mathrm{b}}$ & 36 & 5.9 \\
\hline \multirow[t]{2}{*}{ Residence } & Urban & 50 & 8.1 \\
\hline & Rural & 565 & 91.9 \\
\hline \multirow[t]{3}{*}{ Monthly income } & $<2000$ & 201 & 32.7 \\
\hline & $2000-3500$ & 393 & 63.9 \\
\hline & $\geq 3500$ & 21 & 3.4 \\
\hline \multirow[t]{3}{*}{ Family size } & $1-3$ & 185 & 30.1 \\
\hline & $4-6$ & 362 & 58.9 \\
\hline & $\geq 7$ & 68 & 11.1 \\
\hline
\end{tabular}

\footnotetext{
${ }^{\text {a }}$ Laborer and student.

b Self-employed and laborer.
}

Table 2

Obstetric and pregnancy related characteristics of pregnant mothers in Farta district, South Gondar Zone, Northwest Ethiopia, $2021(\mathrm{n}=615)$.

\begin{tabular}{|c|c|c|c|}
\hline Variables & & frequency & Percent (\%) \\
\hline \multirow[t]{2}{*}{ Gravidity } & Yes & 557 & 90.6 \\
\hline & No & 58 & 9.4 \\
\hline \multirow[t]{3}{*}{ Number of gravidity } & $0-2$ & 166 & 29.8 \\
\hline & $3-5$ & 366 & 65.7 \\
\hline & $\geq 5$ & 25 & 4.5 \\
\hline \multirow[t]{2}{*}{ Parity } & Yes & 557 & 90.6 \\
\hline & No & 58 & 9.4 \\
\hline \multirow[t]{3}{*}{ Number of parity } & $<2$ & 164 & 29.4 \\
\hline & $3-5$ & 371 & 66.6 \\
\hline & $\geq 5$ & 22 & 3.9 \\
\hline \multirow{3}{*}{ Pregnancy interval } & $<2$ & 41 & 7.4 \\
\hline & $3-5$ & 485 & 87.1 \\
\hline & $\geq 5$ & 31 & 5.6 \\
\hline \multirow[t]{2}{*}{ Child death } & Yes & 27 & 4.8 \\
\hline & No & 530 & 95.2 \\
\hline \multirow[t]{3}{*}{ Time of child death } & With in 1 month & 7 & 25.9 \\
\hline & 1 month-1 year & 17 & 63.0 \\
\hline & $>1$ year & 3 & 11.1 \\
\hline \multirow[t]{2}{*}{ Place of delivery } & Home & 57 & 10.2 \\
\hline & Health institution & 500 & 89.8 \\
\hline \multirow[t]{2}{*}{ Number of live birth } & $<4$ & 347 & 62.3 \\
\hline & $\geq 4$ & 210 & 37.7 \\
\hline \multirow[t]{2}{*}{ Abortion } & Yes & 35 & 6.3 \\
\hline & No & 522 & 93.7 \\
\hline \multirow[t]{2}{*}{ Number of abortion } & $\leq 2$ & 34 & 97.1 \\
\hline & $\geq 3$ & 1 & 2.9 \\
\hline \multirow[t]{2}{*}{ History of illness } & $\overline{\text { Yes }}$ & 48 & 7.8 \\
\hline & No & 567 & 92.2 \\
\hline \multirow[t]{2}{*}{ ANC } & Yes & 583 & 94.8 \\
\hline & No & 32 & 5.2 \\
\hline \multirow[t]{4}{*}{ Number of ANC } & 1 & 72 & 12.3 \\
\hline & 2 & 224 & 38.4 \\
\hline & 3 & 208 & 35.7 \\
\hline & 4 & 79 & 13.6 \\
\hline \multirow[t]{3}{*}{ Initiation time of ANC } & First trimester & 75 & 12.9 \\
\hline & Second trimester & 504 & 86.4 \\
\hline & Third trimester & 4 & 0.7 \\
\hline \multirow[t]{3}{*}{ Stage of pregnancy } & First trimester & 64 & 10.5 \\
\hline & Second trimester & 234 & 38.0 \\
\hline & Third trimester & 317 & 51.5 \\
\hline
\end{tabular}

\subsection{Dietary knowledge of the pregnant mothers}

In this study, $188(30.6 \%)$ of the study participants had good dietary knowledge and 427 (69.4\%) had poor dietary knowledge. Except, for the knowledge about carbohydrates source foods (56.1\%), iodine source foods (27.8\%), vitamin A source foods (51.4\%), and iron source foods (49.6\%), other knowledge variables scored $\geq 75 \%$ indicating good dietary knowledge (Table 3).

\subsection{Dietary practices of the pregnant mothers}

In this study $86 \%$ of pregnant mother avoid certain foods, of which $90.6 \%$ avoids food due to personal dislike. The majority $(77.2 \%)$ of the participants skips their usual meal and the most commonly skipped meal was breakfast. Of all 104 (16.9\%) who took an additional meal; 67 (77.4\%) of them took one additional meal. Concerning consumption of macro and micronutrient source foods $77.4 \%$ and $35.1 \%$ were consuming, protein and vitamin-rich foods like fresh vegetables respectively. Most (90.4\%) of pregnant mothers were using non-iodized salt. Ninety-seven percent of pregnant mothers are supplemented with iron. Generally, the majority (72.8\%) of the study participants had poor dietary practices and the remaining $27.2 \%$ of the study participants had good dietary practices (Table 4).

\subsection{Factors associated with dietary practices of pregnant women}

On bivariate analysis, the factors found to be significantly associated 
Table 3

Dietary knowledge of pregnant mothers in Farta district, South Gondar Zone, Northwest Ethiopia, $2021(\mathrm{n}=615)$.

\begin{tabular}{llll}
\hline Variables & & Frequency & $\begin{array}{l}\text { Percent } \\
(\%)\end{array}$ \\
\hline Have you heard about nutrition? & Yes & 604 & 98.2 \\
& No & 11 & 1.8 \\
Where do you heard? & Mass media & 9 & 1.5 \\
& School & 61 & 9.9 \\
& Health & 517 & 84.1 \\
& institution & & \\
Is a balanced diet important during & Others & 17 & 2.8 \\
pregnancy? & Yes & 15 & 2.4 \\
Do you know food is important for & No & 600 & 97.6 \\
body's heat and energy of the body? & Yes & 14 & 2.3 \\
Do you know food is important for & Yes & 601 & 97.7 \\
proper functioning of the body? & No & 13 & 2.1 \\
Do you know food is important for & Yes & 602 & 97.9 \\
infection fighting? & No & 522 & 84.9 \\
Do you know about the main food & Yes & 10 & 15.1 \\
groups of balanced diet? & No & 605 & 1.6 \\
Do you know about the main food & Yes & 85 & 98.4 \\
source of protein? & No & 530 & 13.8 \\
Do you know the main food source of & Yes & 229 & 86.2 \\
carbohydrates? & No & 386 & 62.8 \\
Do you know the main food source of & Yes & 316 & 51.4 \\
vitamin A? & No & 299 & 48.6 \\
Do you know about the main food & Yes & 171 & 27.8 \\
source of iodine & No & 444 & 72.2 \\
Do you know the main food source of & Yes & 305 & 49.6 \\
iron? & No & 310 & 50.4 \\
\hline
\end{tabular}

with good dietary practice were: educational status of mothers, husband's educational status, average monthly income, family size, residence, and nutritional knowledge.

From the variables found to be significant in the bivariate analysis; average monthly income ( $\geq 3500$ ETB) [AOR: 12.03 (95\% CI: I2.83,51.17)], family size (1-3) [AOR: 5.66 (95\% CI: $2.03,15.83)] \&$ (4-6) [AOR: 2.84 (95\% CI: 1.05, 7.67)], educational status (formal education) [AOR:7.61 (95\% CI: 3.64, 15.91)] and dietary knowledge [AOR: 1.99 (95\% CI: 1.27, 3.12)] were found to be significantly associated with good dietary practices in multivariable logistic regression analysis (Table 5).

\section{Discussion}

Maternal undernutrition remains a critical public health problem; which causes a burden of underweight, anemia, and micronutrient deficiencies across the globe. So this community-based cross-sectional study had tried to determine the prevalence of dietary practice among pregnant mothers who live in Farta district.

The study revealed that only $27.2 \%$ with $95 \%$ CI $(23.8,30.7)$ of pregnant mothers had good dietary practices. This figure was in-line with a study conducted in, Ambo district, West Shoa Zone, Oromia, Ethiopia, ${ }^{18}$ However, the current study is higher than the study conducted in West Gojjam Zone, Northwest Ethiopia 19.9\%. ${ }^{19}$ The discrepancy might be attributable to differences in the study period. In addition in this study majority (94.8\%) of the respondents had at least one antenatal care visit; this may create a chance for pregnant mothers to gain information about nutritional practice.

The current study is lower than the study findings in Gondar Town North West, Ethiopia, 40.1\%, ${ }^{20}$ Bahir Dar city Northwestern Ethiopia $39.3 \%,{ }^{15}$ and Dessie town which found $45.2 \%{ }^{21}$ of good dietary practice among pregnant mothers. The discrepancy between the studies might be due to differences in the study settings since the current study was conducted among rural residents with little access to nutrition education and health services. Moreover, respondents in this study had a low level of education. Their literacy level has been a barrier to access information
Table 4

Dietary practice of pregnant mothers in Farta district, South Gondar Zone, Northwest Ethiopia, $2021(\mathrm{n}=615)$.

\begin{tabular}{|c|c|c|c|}
\hline Variables & & Frequency & $\begin{array}{l}\text { Percent } \\
(\%)\end{array}$ \\
\hline \multirow{2}{*}{$\begin{array}{l}\text { Do you crave food not normally } \\
\text { consumed? }\end{array}$} & No & 94 & 15.3 \\
\hline & Yes & 521 & 84.7 \\
\hline \multirow{2}{*}{$\begin{array}{l}\text { Do you avoid any food items } \\
\text { during current pregnancy? }\end{array}$} & No & 529 & 86.0 \\
\hline & Yes & 86 & 14.0 \\
\hline \multirow{3}{*}{$\begin{array}{l}\text { Reason to avoid food during } \\
\text { pregnancy }\end{array}$} & Personal dislike & 77 & 90.6 \\
\hline & Religion & 1 & 1.2 \\
\hline & Makes fetus big & 7 & 8.2 \\
\hline \multirow{2}{*}{$\begin{array}{l}\text { Do you Follow specific dietary } \\
\text { regimen? }\end{array}$} & No & 145 & 23.6 \\
\hline & Yes & 470 & 76.4 \\
\hline \multirow[t]{3}{*}{ How many times you eat per day? } & $\leq 2$ & 25 & 4 \\
\hline & $3-4$ & 546 & 88.8 \\
\hline & $\geq 5$ & 44 & 7.2 \\
\hline \multirow{2}{*}{$\begin{array}{l}\text { Do you have a habit of eating } \\
\text { snack? }\end{array}$} & No & 417 & 67.8 \\
\hline & Yes & 198 & 32.2 \\
\hline \multirow{2}{*}{$\begin{array}{l}\text { Do you skip any meal during } \\
\text { current pregnancy? }\end{array}$} & No & 140 & 22.8 \\
\hline & Yes & 475 & 77.2 \\
\hline \multirow[t]{3}{*}{ Which meal do you skip? } & break fast & 78 & 54.2 \\
\hline & Lunch & 56 & 38.9 \\
\hline & Dinner & 10 & 6.9 \\
\hline \multirow[t]{2}{*}{ Do you eat additional food? } & No & 511 & 83.1 \\
\hline & Yes & 104 & 16.9 \\
\hline \multirow[t]{2}{*}{ Number of additional foods } & 1 & 65 & 77.4 \\
\hline & 2 & 19 & 22.6 \\
\hline \multirow{2}{*}{$\begin{array}{l}\text { Do you eat protein rich foods } \\
\text { during current pregnancy? }\end{array}$} & No & 428 & 69.6 \\
\hline & Yes & 187 & 30.4 \\
\hline \multirow{2}{*}{$\begin{array}{l}\text { Do you have a habit of eating } \\
\text { fresh fruits and vegetable? }\end{array}$} & No & 345 & 56.1 \\
\hline & Yes & 270 & 43.9 \\
\hline \multirow{2}{*}{$\begin{array}{l}\text { Which type of salt you use in your } \\
\text { food? }\end{array}$} & Iodized salt & 554 & 90.1 \\
\hline & Not iodized salt & 61 & 9.9 \\
\hline \multirow[t]{4}{*}{$\begin{array}{l}\text { When you add salt in cooking } \\
\text { food? }\end{array}$} & $\begin{array}{l}\text { At the end of } \\
\text { cooking }\end{array}$ & 43 & 7.0 \\
\hline & $\begin{array}{l}\text { At the middle of } \\
\text { cooking }\end{array}$ & 566 & 92.0 \\
\hline & $\begin{array}{l}\text { At the beginning of } \\
\text { cooking }\end{array}$ & 5 & 0.8 \\
\hline & $\begin{array}{l}\text { Cook without any } \\
\text { salt }\end{array}$ & 1 & 0.2 \\
\hline \multirow{2}{*}{$\begin{array}{l}\text { Do you drink adequate amount of } \\
\text { fluid per day? }\end{array}$} & No & 24 & 3.9 \\
\hline & Yes & 591 & 96.1 \\
\hline \multirow[t]{2}{*}{ Do you drink coffee or tea? } & No & 223 & 36.3 \\
\hline & Yes & 392 & 63.7 \\
\hline \multirow{2}{*}{$\begin{array}{l}\text { How much do you drink coffee or } \\
\text { tea per day? }\end{array}$} & $<3$ cups & 71 & 18.1 \\
\hline & $\geq 3$ cups & 322 & 81.9 \\
\hline \multirow{2}{*}{$\begin{array}{l}\text { Do you have iron supplement } \\
\text { during current pregnancy? }\end{array}$} & No & 19 & 3.1 \\
\hline & Yes & 596 & 96.9 \\
\hline \multirow[t]{2}{*}{ Did you drink alcohol? } & No & 48 & 7.8 \\
\hline & Yes & 567 & 92.2 \\
\hline
\end{tabular}

related to good nutrition practices.

The finding of this study identified that the educational status of pregnant mothers had a strong association with good dietary practices. Which is supported by the study conducted in Egypt in which women with a high level of education had a high level of nutritional knowledge and practice compared to low and moderate educational levels. ${ }^{22}$

The current study showed that there was a strong negative association between family size of pregnant mothers and their dietary practice. The pregnant mothers whose family size ranges from 1 to 3 were 5.66 times more likely to have good dietary practice than those who have a family size of $\geq 7$. And mothers who had family sizes $4-6$ were 2.84 times more likely to have good dietary practice than those who had $\geq 7$. This finding is supported by the study conducted in Illu Aba Bora Zone, Southwest Ethiopia. ${ }^{23}$ Increased family size may adversely affect the nutritional status of every member of the household, including pregnant mothers. Because the larger the family size the lesser food availability to each person within the household which affects nutritional practice.

The finding of this study revealed that average monthly income has a strong statistical association with good dietary practices of mothers during pregnancy. Pregnant mothers who had an average monthly 
Table 5

Bivariate and multivariable logistic regression analysis of factors associated with dietary practice of pregnant mothers in Farta district, South Gondar Zone, Northwest Ethiopia, 2021 ( $\mathrm{n}=615)$.

\begin{tabular}{|c|c|c|c|c|c|}
\hline \multirow[t]{2}{*}{ Variables } & & \multicolumn{2}{|c|}{$\begin{array}{l}\text { Dietary } \\
\text { practice }\end{array}$} & \multirow[t]{2}{*}{$\begin{array}{l}\text { COR with 95\% } \\
\text { CI }\end{array}$} & \multirow[t]{2}{*}{$\begin{array}{l}\text { AOR with } \\
95 \% \text { CI }\end{array}$} \\
\hline & & Good & Poor & & \\
\hline \multirow[t]{3}{*}{ Education } & $\begin{array}{l}\text { Unable to } \\
\text { read and } \\
\text { write }\end{array}$ & 73 & 337 & 1 & 1 \\
\hline & $\begin{array}{l}\text { Able to read } \\
\text { and write }\end{array}$ & 41 & 98 & $\begin{array}{l}1.93(1.24, \\
3.01)^{* *}\end{array}$ & $\begin{array}{l}1.31 \\
(0.8,2.15)\end{array}$ \\
\hline & $\begin{array}{l}\text { Formal } \\
\text { education }\end{array}$ & 53 & 13 & $\begin{array}{l}18.82(9.75 \\
36.32)^{* *}\end{array}$ & $\begin{array}{l}7.61 \\
(3.64,15.91) \\
* *\end{array}$ \\
\hline \multirow[t]{3}{*}{$\begin{array}{l}\text { Husband's } \\
\text { education }\end{array}$} & $\begin{array}{l}\text { Unable to } \\
\text { read and } \\
\text { write }\end{array}$ & 68 & 327 & 1 & 1 \\
\hline & $\begin{array}{l}\text { Able to read } \\
\text { and write }\end{array}$ & 46 & 106 & $\begin{array}{l}2.09(1.35 \\
3.22)^{* *}\end{array}$ & $\begin{array}{l}2.11(0.79, \\
5.67)\end{array}$ \\
\hline & $\begin{array}{l}\text { Formal } \\
\text { education }\end{array}$ & 53 & 15 & $\begin{array}{l}16.99(9.05 \\
31.9)^{* *}\end{array}$ & $\begin{array}{l}2.05(0.33, \\
12.86)\end{array}$ \\
\hline \multirow{3}{*}{$\begin{array}{l}\text { Monthly } \\
\text { income }\end{array}$} & $<2000$ & 59 & 142 & 1 & 1 \\
\hline & $2000-3500$ & 91 & 302 & $\begin{array}{l}0.73 \\
(0.49,1.06)^{*}\end{array}$ & $\begin{array}{l}0.7 \\
(0.45,1.11)\end{array}$ \\
\hline & $\geq 3500$ & 17 & 4 & $\begin{array}{l}10.23(3.30 \\
31.69)^{* *}\end{array}$ & $\begin{array}{l}12.03(2.83 \\
51.17)^{* *}\end{array}$ \\
\hline \multirow[t]{2}{*}{ Residence } & Rural & 128 & 437 & 1 & 1 \\
\hline & Urban & 39 & 11 & $\begin{array}{l}12.1(6.03 \\
24.32)^{* *}\end{array}$ & $\begin{array}{l}1.53(0.59 \text {, } \\
3.99)\end{array}$ \\
\hline \multirow[t]{3}{*}{ Family size } & $1-3$ & 87 & 98 & $\begin{array}{l}7.74(3.36 \\
17,81)^{* *}\end{array}$ & $\begin{array}{l}5.66 \\
(2.03,15.83) \\
* *\end{array}$ \\
\hline & $4-6$ & 73 & 289 & $\begin{array}{l}2.2(0.97, \\
5.01)\end{array}$ & $\begin{array}{l}2.84(1.05, \\
7.67)^{*}\end{array}$ \\
\hline & $\geq 7$ & 7 & 61 & 1 & 1 \\
\hline Nutritional & Poor & 70 & 339 & 1 & 1 \\
\hline knowledge & Good & 97 & 109 & $\begin{array}{l}4.310 \\
(2.960-6.274) \\
* *\end{array}$ & $\begin{array}{l}1.99(1.27 \\
3.12)^{* *}\end{array}$ \\
\hline
\end{tabular}

*Significant at $\mathrm{p}<0.05, * *$ Significant at $\mathrm{p}<0.01$.

income greater than or equal to 3500 ETB were 12 times more likely to have good dietary practice than those earning less than 2000 ETB. Similar findings had also been reported from a study in Wondo Genet, Southern Ethiopia that identified average monthly income had a significant association with the dietary practice of pregnant mothers. ${ }^{24}$ The possible reason might be families with low income may eat a less nutritious diet than those with a higher income, either because they cannot afford enough food or they eat nutritionally poor foods.

In this study; nutritional knowledge during pregnancy had a significant association with the participant's dietary practice. Pregnant mothers who were knowledgeable about nutrition were two times more likely to have good dietary practice during pregnancy than their counterparts. This finding was similar to a study that was conducted in Gedeo Zone, Southern Ethiopia. ${ }^{25}$ The reason might be due to more exposure of pregnant women to dietary information; they become informed about the consequences of undernutrition on themselves and their fetus which will be enforced to practice adequate diet.

\section{Limitations of the study}

This study acknowledged some important possible limitations that should be considered when interpreting the results. First, the study was cross-sectional, a design that does not permit to establish cause-effect relationships. Second, recall bias might be introduced.

\section{Conclusion}

In this study, more than a quarter of pregnant mothers had good dietary practice. Educational status of the participants, dietary knowledge, monthly income, and family size were significantly associated with dietary practices of pregnant women. To improve dietary practice of pregnant women; enhance knowledge on nutrition through nutrition education and decrease family size by regular family planning counseling in the continuum of maternal care.

\section{Ethics approval and consent to participate}

This study was conducted under the declaration of Helsinki. Ethical clearance was obtained from the School of Midwifery (SMIDW/18/2013 9.9D) under the delegation from the Ethical Review Board of the University of Gondar. A formal letter of cooperation was written for the Farta district health office and permission was obtained. Informed written consent was taken from each study participant. Any involvement in the study was after complete consent was obtained. All data was kept confidentially by using codes.

\section{Consent for publication}

Not applicable.

\section{Data sharing statements}

The datasets collected and analyzed for this study are available from the principal investigator and can be attained on a reasonable request.

\section{Funding statement}

The funding source of this research was the University of Gondar and the University has no role in design, data collection, analysis, decision to publish as well as preparation of the manuscript.

\section{Authors' contributions}

All the authors had significant involvement in the conception and designing the study, acquisition of data, analysis, and interpretation of data, took part in drafting the article, revising the article, gave final approval of the version to be published, have agreed on the journal to which the article has been submitted and agree to be accountable for all aspects of the work.

\section{Declaration of competing interest}

The authors declare that they have no competing interests.

\section{Acknowledgments}

We would like to thank the University of Gondar for its financial support. We deeply appreciate the data collectors and the study participants.

\section{Appendix A. Supplementary data}

Supplementary data to this article can be found online at https://doi. org/10.1016/j.cegh.2022.100968. 


\section{References}

1 Williamson C. Nutrition in pregnancy. Nutr Bull. 2006;31(1):28-59.

2 WHO. Nutrition. 2019.

3 Triunfo S, Lanzone A. Impact of maternal under nutrition on obstetric outcomes. J Endocrinol Invest. 2015;38(1):31-38.

4 Dukhi N. Global Prevalence of Malnutrition: Evidence from Literature. Malnutrition: IntechOpen; 2020.

5 Black R, Hopkins Bloomberg J. The lancet series on maternal and child Undernutrition, executive summary. Lancet. 2008;371:1-10.

6 Bhutta ZA, Das JK, Rizvi A, et al. Evidence-based interventions for improvement of maternal and child nutrition: what can be done and at what cost? Lancet. 2013;382 (9890):452-477.

7 Anyasor Chiamaka Ogechi1* OOH. Factors influencing the nutritional practice of pregnant women living in a semi-urban region of ogun state, Nigeria. Saudi Journal of Medicine. 2017;-2.

8 I K. Determinants of Adverse Maternal and Feotal Outcomes Among Women in Kamwenge District, South Western Uganda. CIU; 2017.

9 Nnam NM. Improving maternal nutrition for better pregnancy outcomes. Proc Nutr Soc. 2015;74(4):454-459.

10 Desyibelew HD, Dadi AF. Burden and determinants of malnutrition among pregnant women in Africa: a systematic review and meta-analysis. PLoS One. 2019;14(9), e0221712.

11 International ICCSAEaI. Ethiopia Demographic and Health Survey. 2018.

12 Taddese A, Zerfu MU, Baye Kaleab. Dietary Diversity during Pregnancy Is Associated with Reduced Risk of Maternal Anemia, Preterm Delivery, and Low Birth Weight in a Prospective Cohort Study in Rural Ethiopia. ASN est; 2016, 1928.

13 GotFDR E. National Nutrition Programme June 2013-June 2015. Addis Ababa: Government of Federal Democratic Republic of Ethiopia. 2013.

14 National. Central Statistical Agency. 2011.

15 Nana A, Zema T. Dietary practices and associated factors during pregnancy in northwestern Ethiopia. BMC Pregnancy Childbirth. 2018;18(1):1-8.
16 Demilew YM, Alene GD, Belachew T. Effect of guided counseling on dietary practices of pregnant women in West Gojjam Zone, Ethiopia. PLoS One. 2020;15(5), e0233429.

17 Daba G, Beyene F, Garoma W, Fekadu H. Assessment of nutritional practices of pregnant mothers on maternal nutrition and associated factors in Guto Gida Woreda, east Wollega zone, Ethiopia. Sci Technol Arts Res J. 2013;2(3):105-113.

18 Tolera B, Mideksa S, Dida N. Assessment of dietary practice and associated factors among pregnant mother in Ambo District, West Shoa, Oromia, Ethiopia, 2018. Ethiopian Journal of Reproductive Health. 2018;10(4).

19 Demilew YM, Alene GD, Belachew T. Dietary practices and associated factors among pregnant women in West Gojjam Zone, Northwest Ethiopia. BMC Pregnancy Childbirth. 2020;20(1):1-11.

20 Alemayehu MS, Tesema EM. Dietary practice and associated factors among pregnant women in Gondar town north west, Ethiopia, 2014. Int J Nutr Food Sci. 2015;4(6): 707-712.

21 Diddana TZ, Kelkay GN, Dola AN, Sadore AA. Effect of nutrition education based on health belief model on nutritional knowledge and dietary practice of pregnant women in Dessie Town, Northeast Ethiopia: a cluster randomized control trial. Journal of Nutrition and Metabolism. 2018;2018.

22 Alkalash SH, Hegazy NN, ELnady RT, Khalil NA. Dietary practice and nutritional status among pregnant women. The Egyptian Journal of Hospital Medicine. 2021;83(1); 1030-1037.

23 Tsegaye D, Tamiru D, Belachew T. Factors associated with dietary practice and nutritional status of pregnant women in rural communities of Illu Aba bor zone, southwest Ethiopia. Nutr Diet Suppl. 2020;12:103-112.

24 Kuche D, Singh P, Moges D. Dietary practices and associated factors among pregnant women in Wondo Genet District, southern Ethiopia. J Pharmaceut Sci Innovat. 2015;4 (5):270-275.

25 Yalewdeg M, Birhane M, Adissu Y. Dietary practices and their determinants among pregnant women in Gedeo zone, southern Ethiopia: a community-based crosssectional study. Nutr Diet Suppl. 2020;12:267. 